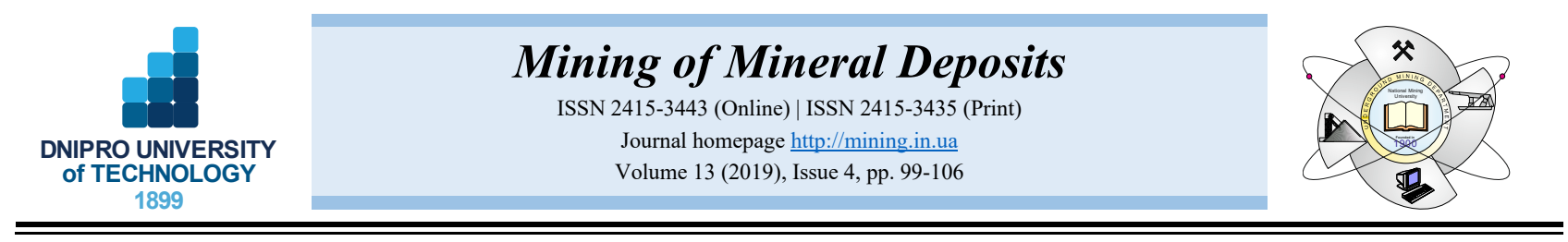

UDC 622.23

https://doi.org/10.33271/mining13.04.099

\title{
THREE-DIMENSIONAL ELECTROMAGNETIC FIELD MODEL OF AN AUGER ELECTROMECHANICAL CONVERTER WITH AN EXTERNAL SOLID ROTOR
}

\author{
M. Zablodskiy ${ }^{1}$, V. Gritsyuk ${ }^{2 *}$, Ye. Rudnev ${ }^{2}$, R. Brozhko² \\ ${ }^{\prime}$ National University of Life and Environmental Sciences of Ukraine, Kyiv, Ukraine \\ ${ }^{2}$ Volodymyr Dahl East Ukrainian National University, Sieverodonetsk, Ukraine \\ *Corresponding author: e-mail gritsyukvy@gmail.com, tel.+380999485433
}

\begin{abstract}
Purpose. Creating a three-dimensional mathematical model of the electromagnetic field of an auger electromechanical converter with the external solid rotor, taking into account the geometry peculiarities and the finite length factor.

Methods. Calculation of the electromagnetic field distribution has been performed with the use of the computational solving the differential equations by the finite element method in a three-dimensional statement.

Findings. It has been set that in the air gap the values of magnetic induction vary in the range of $0.7-0.8 \mathrm{~T}$, in the flanks of the stator teeth they reach the value of $2 \mathrm{~T}$. Induction in a hollow ferromagnetic rotor varies mainly in the range of $1.3-2.0 \mathrm{~T}$, and in a thin layer with a thickness of $1.0-1.5 \mathrm{~mm}$, facing the stator surface, it reaches the value of $2.3 \mathrm{~T}$. Within one pole pitch, the z-component maximum of the eddy currents density is $18 \cdot 10^{6} \mathrm{~A} / \mathrm{m}^{2}$ on the inner hollow rotor surface. It has been determined that, with the exception of the 'edge' rotor sections, where the transverse component of eddy currents prevails, as well as the sections of the magnetic flux "input" into the rotor, the eddy currents are mainly axial. A comparison of the results of measuring the electric field intensity on the rotor surface evidences a data difference of not more than $4 \%$. The proposed model enables to optimize the design of the converter, in particular, to reduce the magnetic induction in the stator teeth.
\end{abstract}

Originality. Numerical results have been obtained in the form of spatial patterns of distribution and graphical dependences that take into complete account the axial and tangential components of the electromagnetic field.

Practical implications. The considered finite element model can be used when analysing the electromagnetic fields in electromechanical converters with a complex secondary part. This will give a possibility to consider the real threedimensional field character, caused by the design peculiarities and the final axial dimensions.

Keywords: coal concentrate, auger electromechanical converter, computational studies, magnetic induction, eddy currents distribution

\section{INTRODUCTION}

The majority of all processed coals is enriched by wet milling methods in the processing plants. Therefore, along with the ash content, sulphur content, calorific value, the moisture content of the shipped coal is one of the most important quality indicators. Reduce in the moisture content of coal concentrates and mud coal is associated with a decrease in the ballast transportation volumes in the form of excess moisture, the prevention of freezing in winter time, and leads to an increase in the efficiency of heat power plants and industrial boiler facilities.

The use of electromechanical converters as the links in the technological chain for the processing of bulk and viscous materials is among the current trends in the field of scientific research of the $21^{\text {st }}$ century. A promising class of Polyfunctional Electromechanical Energy Converters (PEEC), designed for the direct technological processes implementation, is distinguished by an enhanced concentration of functional and energy properties, as well as the almost complete use of electric energy coming from the electrical power network (Zablodskiy, Plyugin, \& Gritsyuk, 2014; Zablodskiy, Plyugin, \& Gritsyuk, 2016).

Creation of PEEC and technologies based on them is grounded upon the idea of combining in one electromechanical device simultaneously heating, transporting, mixing functions, integrating and directing of the heat energy to the raw material processing zone. PEEC uses a hollow ferromagnetic rotor design, which performs simultaneously the functions of the asynchronous motor

(C) 2019. M. Zablodskiy, V. Gritsyuk, Ye. Rudnev, R. Brozhko. Published by the Dnipro University of Technology on behalf of Mining of Mineral Deposits.

This is an Open Access article distributed under the terms of the Creative Commons Attribution License (http://creativecommons.org/licenses/by/4.0/),

which permits unrestricted reuse, distribution, and reproduction in any medium, provided the original work is properly cited. 
rotor, heater, actuator, and protective casing. Moreover, the rotor is cooled by raw materials, which are processed. Air and free-melting materials with high heating capacity and latent heat of melting can act as an additional cooling agent in PEEC. PEEC of the auger type (Fig. 1) consists of two modules operating in the opposite connection mode. Two stators located on a common hollow shaft create counter-directed electromagnetic moments, providing the necessary rotation velocity of the common rotor hollow cylinder without the use of a mechanical gear reducer. A rotor having an auger winding, in addition to the function of moving the working material, provides simultaneously the heating of working material. PEEC have no analogues in the world, which makes it possible to create competitive technologies.

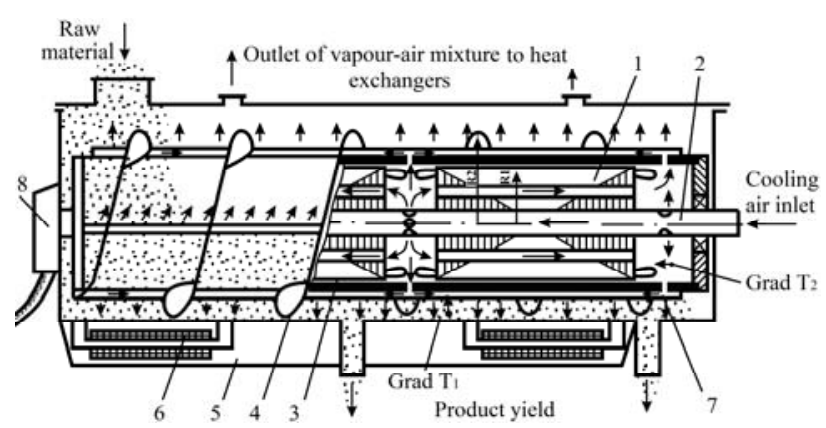

Figure 1. Constructive-and-technological scheme of the auger PEEC: 1-stator of the drive (brake) module; 2 -hollow fixed shaft; 3 -external rotor-auger; 4-auger bottom; 5-casing; 6-bottom heating inductors; 7 - axial channels of the rotor-auger; 8 - supply voltage input

Figure 2 shows a general view of the experimental auger PEEC sample, manufactured at the K. Marx Electromechanical Plant in Pervomaisk. Provided a minimum heat transfer to the environment, the efficiency of the auger PEEC reaches a value of 0.98. Significant advantages of the PEEC-based technologies are not only a high value of efficiency, but also significant reductions in the production area, the number of equipment units and the pay-back time.

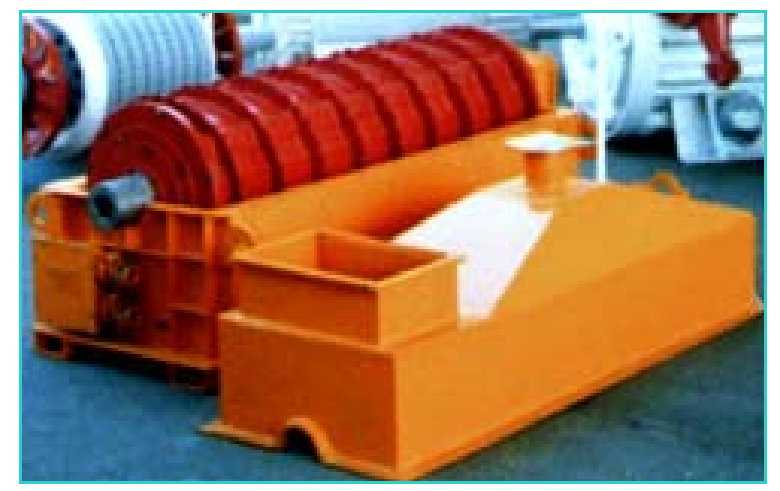

Figure 2. A general view of the auger PEEC with removed upper part of casing

Among the existing devices, the electromechanical converters that combine the functions of transporting the substances and generating the heat energy are similar in their ideology creation. The important results obtained by the authors (Kim \& Ivanov, 2009) include the theoretical substantiation of the design principles of electromechanical pumping over devices. Such devices are represented in the form of asynchronous motors with rotating secondary elements having pressure blades or screw-type winding. Among recent foreign publications there are works devoted to the development of two-stator rotational-linear electromechanical converters that are able to perform rotation and movement along its axis (Amiri, 2014; Szczygieł \& Kluszczyński, 2016). Such devices are of increasing interest and can be usually found in such processes as drilling, mixing, thread cutting, screwing, activating the robot devices. As a rule, the ferromagnetic element with cylindrical shape functions as a rotor of a two-stator rotational-linear converter.

Researchers (Dobzhanskyi \& Gouws, 2013) have shown the advantages of an energy-efficient industrial mixer constructed on the basis of a synchronous electric motor with a solid rotor having permanent magnets. Such converters perform both rotational and linear motion. They can have a multimodule design with any number of modules with a common three-phase winding (Zhao, Xinhui, Xin, \& Han, 2009; Bentia \& Szabó, 2010; Bolognesi, Bruno, Papini, Biagini, \& Taponecco, 2010).

Significant achievements of foreign scientists include the results in the physical processes study in such converters. A large number of works, including (Aho, Nerg, \& Pyrhonen, 2007; Gieras \& Saari, 2012; Papini \& Gerada, 2014), are devoted to electromagnetic and thermal fields study in the active zone of electromechanical converters with a ferromagnetic rotor by means of numerical techniques. In the works of authors (Amiri, Gottipati, \& Mendrela, 2011; Amiri, Jagiela, Dobzhanski, \& Mendrela, 2013), the results are presented of three-dimensional finite element modelling of a rotational-linear motor. A three-dimensional analysis of a rotational-linear converter, which considers the longitudinal and transverse edge effects, the current displacement effect, the influence of the thickness of the core outer sheets, and which practically has no restrictions on the magnetic circuit configuration, is presented in the publication (Alwash \& Qaseer, 2010). In the works (Mendrela, 1978; Fleszer \& Mendrela, 1983; Cathey, 1985; Mendrela \& Geirczak, 1987; Rabiee \& Cathey, 1988), the analysis of an asynchronous converter with spiral motion is given. The authors use the Fourier method of series, which takes into account edge effects.

The optimization of PEEC design to perform the specific technological functions, such as drying and processing of coal concentrates and mud coal, is an important scientific and applied problem of electromechanics. The calculation of real distribution of magnetic induction, eddy currents and electromagnetic forces in the active part of an electromechanical converter is possible with the use of a mathematical model which takes into account the peculiarities of geometry, surface effect, finite length factor, and non-linearity of the electrophysical and magnetic properties of materials. A superprecision approach to modelling, based on three-dimensional numerical analysis, will allow to better understand and predict phenomena that are difficult and sometimes impossible assessed experimentally. 


\section{DETERMINING THE THREE-DIMENSIONAL ELECTROMAGNETIC FIELD DISTRIBUTION}

The rotor of the converter under study is made in the form of an external hollow ferromagnetic cylinder. In the general case, the non-linear magnetic system of the auger PEEC consists of several ferromagnetic bodies with nonlinear physical properties of materials surrounded by a magnetic-linear medium. The electromagnetic field at each point of the studied area is determined by the magnetic induction vectors $B$ of the magnetic field intensity $H$ of the electric displacement $D$ and the electric field intensity $E$.

The system of Maxwell's equations for the electromagnetic field vectors in all areas of the auger PEEC is a mathematical model of non-linear magnetic system with a current densities distribution.

In the practice of electromechanical converters (EC) fields calculations, to bring the Maxwell's equations system to a form more convenient for solving, the vector magnetic potential $A$ is often used, which is determined by the expression:

$\operatorname{rot} \vec{A}=\vec{B}$.

Based on the Maxwell's equations, in media with non-linear magnetic characteristics, when using the vector magnetic potential, an equation can be written, which describes the electromagnetic field for randomly time-varying distributed alternating currents, including eddy currents in massifs.

Ampere's circuital law with account of (1) and the properties of the media:

$\operatorname{rot}\left(\frac{1}{\mu} \operatorname{rot} \vec{A}\right)=\vec{J}_{e d d y}+\vec{J}_{e x t}$,

where:

$\mu=\mu_{0} \cdot \mu_{r}-$ absolute magnetic permeabilty;

$\mu_{0}$ - magnetic permeability in vacuum;

$\mu_{r}$ - relative magnetic permeability;

$\vec{J}_{e d d y}$ - eddy currents density;

$\vec{J}_{\text {ext }}$ - extraneous currents density.

Using the scalar magnetic potential $\varphi$, the expression for the eddy currents density can be written:

$$
\vec{J}_{e d d y}=\gamma\left(-\frac{\partial \vec{A}}{\partial t}+\operatorname{grad} \phi\right)
$$

where:

$\gamma$-specific electrical conductivity.

Having substituted the expression for the eddy currents density into equation (2) and accepting the calibration conditions $\operatorname{div} A=\mu \gamma \varphi$, let us perform the vector transformations and obtain the differential equation of the electromagnetic field in the partial derivatives according to the vector magnetic potential:

$\operatorname{rot}\left(\frac{1}{\mu} \operatorname{rot} \vec{A}\right)-\gamma \frac{\partial \vec{A}}{\partial t}-\gamma(\vec{v} \times \operatorname{rot} \vec{A})=-\vec{J}_{\text {ext }}$,

where: $\vec{v}$ - velocity vector of the electrically conducting medium movement relative to the magnetic field source.

For the case when the magnetic field varies in harmonic law, the equation (4) takes the form:

$\operatorname{rot}\left(\frac{1}{\mu} \operatorname{rot} \vec{A}\right)-j \omega \gamma \vec{A}-\gamma \vec{v} \cdot(\operatorname{rot} \vec{A})=-\vec{J}_{\text {ext }}$,

where:

$\omega$ - angular frequency of the magnetic field changes.

For non-conducting areas, the Poisson's equation is valid:

$\operatorname{rot}\left(\frac{1}{\mu} \operatorname{rot} \vec{A}\right)=-\vec{J}_{\text {ext }}$.

The solution of lengthy equations of the field in the numerical calculations of three-dimensional models is accompanied by significant difficulties. From the point of view of optimizing the hardware costs, it is expedient to perform the numerical calculation of a quasi-stationary electromagnetic field using the equation for the rotor coordinate system, since there is no convection component related to the rotor rotation relative to the coordinate system. Simplification of the equation (5), through the exclusion of the convection term, does not affect the approach to solving the problem, however, it contributes to the solution convergence, which enables to implement practically the algorithm of numerical calculation.

In the case of using a rotor coordinate system, the rotor remains motionless. Then, in the equation (5), it is necessary to accept the conditions:

$\omega=\omega_{1} s ; \omega_{R}=0 ; v_{x}=v_{y}=0$,

where:

$\omega_{1}$ - angular frequency of the stator field rotation;

$s-$ rotor slip

$\omega_{R}-$ angular frequency of the rotor rotation;

$v_{x, y}$-components of the velocity vector of the electrically conducting medium relative to the magnetic field source.

Finally, the equation (5) can be written as:

$\operatorname{rot}\left(\frac{1}{\mu} \operatorname{rot} \vec{A}\right)-j \omega_{1} s \gamma \vec{A}=-\vec{J}_{\text {ext }}$.

If in two-dimensional problems one component of $\vec{A}$ vector describes two components of the magnetic field, then, all three components should be considered in threedimensional problems. The vector equation (8) for a threedimensional magnetic field is equivalent to three equations:

$$
\begin{aligned}
& \frac{\partial}{\partial x} \frac{1}{\mu} \frac{\partial A_{x}}{\partial x}+\frac{\partial}{\partial y} \frac{1}{\mu} \frac{\partial A_{x}}{\partial y}+\frac{\partial}{\partial z} \frac{1}{\mu} \frac{\partial A_{x}}{\partial z}-j \omega_{1} s \gamma A_{x}=-J_{x} ; \\
& \frac{\partial}{\partial x} \frac{1}{\mu} \frac{\partial A_{y}}{\partial x}+\frac{\partial}{\partial y} \frac{1}{\mu} \frac{\partial A_{y}}{\partial y}+\frac{\partial}{\partial z} \frac{1}{\mu} \frac{\partial A_{y}}{\partial z}-j \omega_{1} s \gamma A_{y}=-J_{y} ; \\
& \frac{\partial}{\partial x} \frac{1}{\mu} \frac{\partial A_{z}}{\partial x}+\frac{\partial}{\partial y} \frac{1}{\mu} \frac{\partial A_{z}}{\partial y}+\frac{\partial}{\partial z} \frac{1}{\mu} \frac{\partial A_{z}}{\partial z}-j \omega_{1} s \gamma A_{z}=-J_{z},
\end{aligned}
$$

where: 
$J_{x, y, z}$-components of the vector of extraneous currents density.

Equation (8) is supplemented by boundary conditions. At the external boundaries of the computational domain (the three-dimensional model shell), a zero value of the vector magnetic potential is set (Dirichlet condition):

$\vec{A}=0$.

The boundary condition (9) stipulates the accepted assumption that there are no magnetic fluxes leakage into the outer space through the considered boundaries. At the interface between media with different magnetic properties, the condition of normals equality to the boundary of the components of the magnetic induction vector and the tangent components of the magnetic field vector intensity is used (Neumann condition):

$$
\vec{B}_{n_{2}}=\vec{B}_{n_{2}} ; \vec{H}_{\tau_{1}}=\vec{H}_{\tau_{2}} .
$$

Let us set the dependences of the media parameters on the spatial coordinates. Magnetic permeability as a function of magnetic field intensity for ferromagnetic media of the studied system in a matrix form:

$$
\left[\mu_{r}\right]=\left[\begin{array}{ccc}
\mu_{r x} & 0 & 0 \\
0 & \mu_{r y} & 0 \\
0 & 0 & \mu_{r z}
\end{array}\right],
$$

where:

$\mu_{r x}, r y, r z$ - relative magnetic permeability along the $x$, $y, z$ axes, respectively.

The conductivity matrix for conducting media has the form:

$$
\left[\mu_{r}\right]=\left[\begin{array}{ccc}
\gamma_{x} & 0 & 0 \\
0 & \gamma_{x} & 0 \\
0 & 0 & \gamma_{x}
\end{array}\right],
$$

where:

$\gamma_{x}, y, z-$ electrical conductivity along the $x, y, z$ axes, respectively.

The basis for the numerical calculation of the threedimensional quasi-stationary electromagnetic field of the auger PEEC is the partial differential equation (8), which is reducible to the algebraic equations system with respect to the target values of the vector magnetic potential at the nodes of the finite element mesh. The vector magnetic potential is calculated based on the condition of the minimum of energy functional:

$$
\begin{aligned}
& F=\int_{V}\left[\frac{\partial}{\partial x} \frac{1}{\mu} \frac{\partial \vec{A}}{\partial x}+\frac{\partial}{\partial y} \frac{1}{\mu} \frac{\partial \vec{A}}{\partial y}+\frac{\partial}{\partial z} \frac{1}{\mu} \frac{\partial \vec{A}}{\partial z}\right] d x d y d z+ \\
& +\int_{V} j \omega \gamma\left|\overrightarrow{A^{2}}\right| d x d y d z+\int_{V} \vec{J} \vec{A} d x d y d z
\end{aligned}
$$

According to the calculation results of distribution of the vector magnetic potential, values of the magnetic induction, intensity of the magnetic and electric fields are determined. The calculation of currents, losses and forces is carried out by integration over the volumes and the surfaces of the computational domains of a model.
The practical implementation of the mathematical model has been performed within the Comsol Multiphysics 5.2 software and computer complex.

The initial data for calculating the electromagnetic problem are: geometric parameters of the model; angular frequency of the rotor rotation; current density in stator slots; electrical and magnetic properties of materials.

The calculation of three-dimensional distribution of the electromagnetic field has been performed for the drive module of the auger PEEC experimental sample. The model geometry does not contain an auger winding, rotor ventilation holes and bearing shields. The main assumptions are conditioned by the idealization of physical and geometric characteristics of the auger converter design and include the following:

1. The anisotropy of the physical properties of materials is not taken into account.

2 . The relative magnetic permeability of the nonferromagnetic medium is assumed to be unity.

3. The specific electrical conductivity of the stator core is assumed to be zero.

4. The current density in the conductors of the slotted area of the stator winding has only one axial component $-J_{z}\left(J_{x}=J_{y}=0\right)$.

The angular frequency of the rotor rotation is set in the form of the field sources frequency in accordance with the conditions (7) for the rotor coordinate system. The specific electrical conductivity of the rotor material was accepted in accordance with the reference data, taking into account the averaged temperature of $230^{\circ} \mathrm{C}$ (a physical experiment data) with working slip $s=0.88$ for the drive module. The non-linearity of the magnetic properties of the solid rotor and stator core is taken into account by setting the corresponding magnetization curves.

The field sources on the right side of equation (8) are set by the extraneous current density in the slotted areas of the stator according to the three-phase scheme of winding connection. The complex values of the current density in the phases of the stator winding:

$$
\begin{aligned}
& \vec{J}_{A}=\frac{I_{m} \cdot u_{g}}{S_{g}} ; \\
& \vec{J}_{B}=\frac{-I_{m}\left[\cos \left(\frac{-2 \pi}{3}\right)-j \sin \left(\frac{-2 \pi}{3}\right)\right] \cdot u_{g}}{S_{g}} ; \\
& \vec{J}_{C}=\frac{-I_{m}\left[\cos \left(\frac{-4 \pi}{3}\right)-j \sin \left(\frac{-4 \pi}{3}\right)\right] \cdot u_{g}}{S_{g}},
\end{aligned}
$$

where: data);

$I_{m}$ - current amplitude in stator phase (physical model

$u_{\mathrm{g}}$ - the number of effective conductors in the slot;

$S_{g}$ - sectional area of the slot.

In the considered electromagnetic problem, the field distribution immediately in the ferromagnetic rotor, as well as in the air gap zone, is of the greatest interest. The requirements by the discretization degree are specified to the conducting structural elements in which the eddy currents are calculated. The mesh spacing in 
them, as indicated in the literature, should be no more than $1 / 4$ of the field penetration depth. At the same time, to ensure the solution accuracy, the ratio of the maximum spacing to the minimum one should not be more than $8-10$.

The greatest influence on the calculation time (the number of iterations), alongside with the presence of non-linearities, is made by the finite elements dimensions and the degree of the corresponding approximating functions determined by the number of nodes of finite elements. The final choice of parameters and optimization of the mesh structure are carried out in the course of numerical experiments by establishing a compromise between the modelling accuracy and the time spent on the calculations. A three-dimensional finite element mesh of the model is represented in Figure 3. The finite element mesh of air areas located outside the ferromagnetic rotor, inside the fixed shaft, and also along the ends of the active part, is not shown.

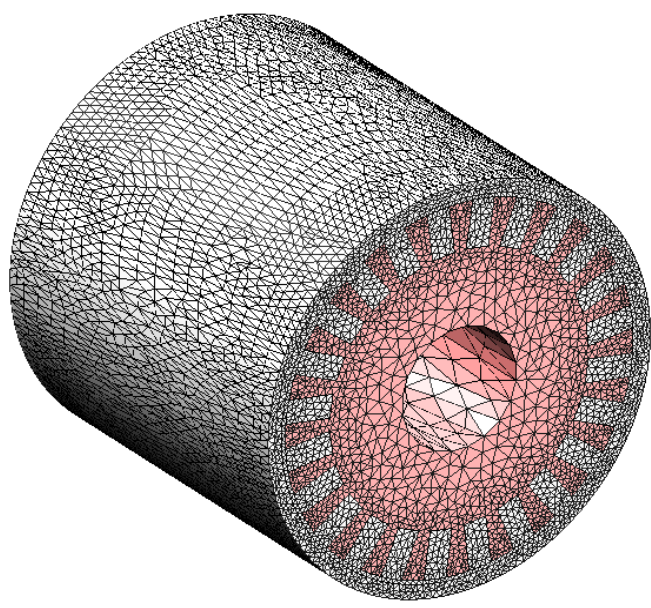

Figure 3. Three-dimensional finite element mesh of the model

\section{RESULTS AND DISCUSSION}

The result of solving the problem of threedimensional distribution of the electromagnetic field is shown in Figure 4 in the form of several longitudinal and transverse cuts of the active part of the drive module of the auger PEEC at $s=0.88$. By colouring with different colors and intensities, the value of the $z$-component of the vector magnetic potential $A_{z}$ is determined.

Figure 5 shows the distribution pattern of a normal component of magnetic induction in the active part of the auger PEEC in the form of a set of longitudinal and transverse cuts of the model with the same slip for the drive module $s=0.88$. While Figure 6 shows the magnetic induction distribution in the hollow rotor wall in the form of a longitudinal cut.

In the air gap, the values of magnetic induction vary in the range of $0.7-0.8 \mathrm{~T}$, in the flanks of the stator teeth they reach the value of $2 \mathrm{~T}$. Induction in a hollow ferromagnetic rotor varies mainly in the range of $1.3-2.0 \mathrm{~T}$, and in a thin layer with a thickness of $1.0-1.5 \mathrm{~mm}$, facing the stator surface, it reaches the value of $2.3 \mathrm{~T}$. The proposed model can enable to optimize the converter design, in particular, to reduce the magnetic induction in the stator teeth.

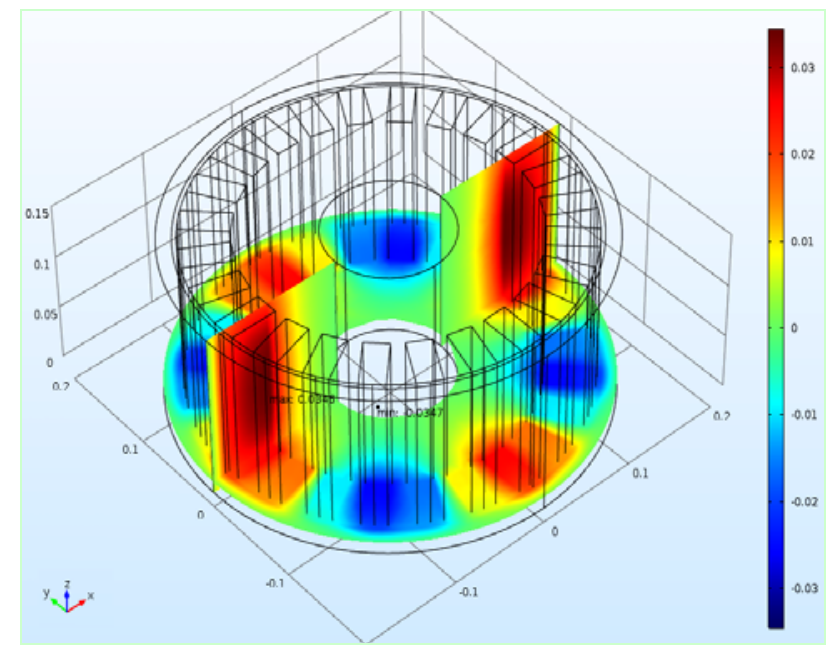

Figure 4. Distribution of a z-component of the vector magnetic potential in the form of longitudinal and transverse cuts of the drive module active part at $s=0.88$

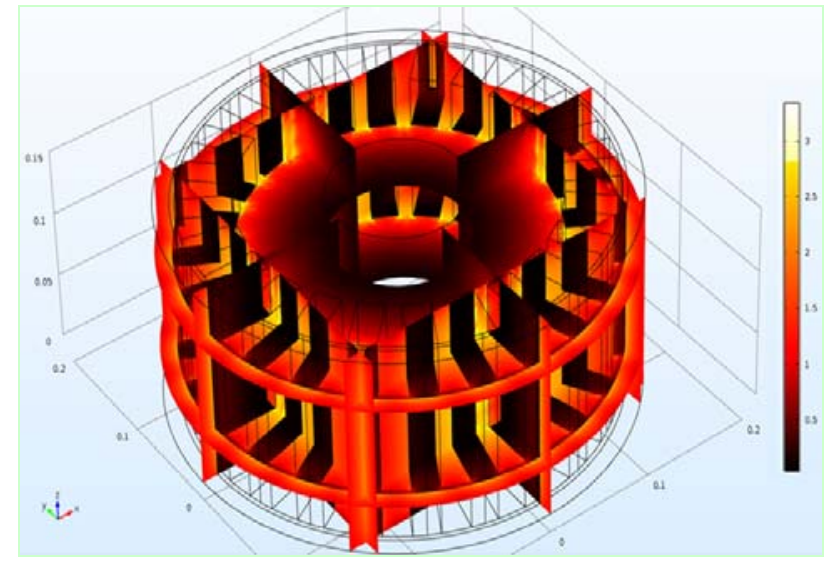

Figure 5. Distribution of a normal component of magnetic induction in the form of longitudinal and transverse cuts of the drive module active part at $s=0.88$

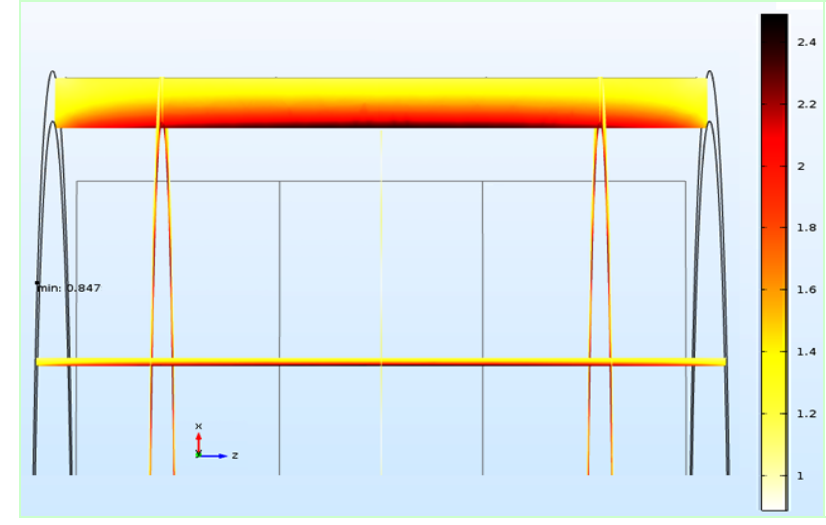

Figure 6. Distribution of a normal component of magnetic induction (T) in the hollow rotor wall in the form of a longitudinal cut

Consider in more detail the distribution of eddy current density ( $z$-component) in the wall of the outer hollow rotor at $s=0.88$ (Fig. 7). It can be seen from the Figure 7 that the eddy currents component, which is perpendicular to the plane of the rotor section, flows in two opposite directions, thereby forming path for current flow. 


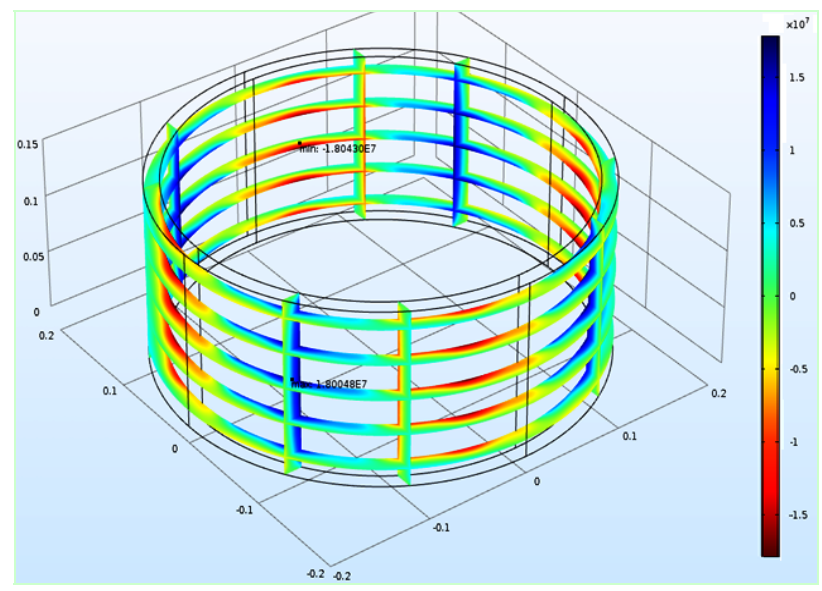

Figure 7. Distribution of a z-component of eddy currents density $\left(A / m^{2}\right)$ in the wall of the outer hollow rotor (in the form of transverse cuts)

At the same time, there are rotor sections, where, on its surface, the currents of one direction flow, and, at a certain depth, the damped currents of opposite direction flow. In this mode, the current frequency in the rotor is $44 \mathrm{~Hz}$, while within the limits of one pole pitch, the $z$-component maximum of the eddy current density was $18 \cdot 10^{6} \mathrm{~A} / \mathrm{m}^{2}$ on the inner hollow rotor surface. With the exception of the "edge" rotor sections, where the transverse component of the eddy currents prevails, as well as the sections of the magnetic flux "input" into the rotor, the eddy currents are mainly axial.

The results obtained using the proposed model have revealed high convergence with the experimental studies results presented earlier in the work (Zablodskiy, Zhiltsov, Kondratenko, \& Gritsyuk, 2017). A comparison of the results of measuring the electric field intensity on the rotor surface evidences a data difference of not more than $4 \%$. The proposed model enables to obtain the numerical results in the form of spatial patterns of distribution and graphical dependences that take into complete account the axial and tangential components of the electromagnetic field.

This, in turn, enables to increase the adequacy of calculations in comparison with existing models developed in the form of a part (three-dimensional sector) of the converter and requiring the use of a symmetry coefficient.

\section{CONCLUSIONS}

The presented three-dimensional mathematical model of the electromagnetic field of the active part of auger electromechanical converter with an external solid rotor takes into account the peculiarities of geometry and the finite length factor. The studied finite element model can be used when analysing the electromagnetic fields in electromechanical converters with a complex secondary part. This will give a possibility to consider a real three-dimensional field character (caused by the design peculiarities and the final axial dimensions) and, accordingly, to obtain more adequate project information.

\section{ACKNOWLEDGEMENTS}

This research would not have been possible without the support provided under the state-financed scientific research theme "Development of subsystem for predicting and controlling the dynamics of methane content at mines". The authors express their gratitude to Professor Mykola Antoshchenko for assistance in conducting the research.

\section{REFERENCES}

Aho, T., Nerg, J., \& Pyrhonen, J. (2007). Experimental and finite element analysis of solid rotor end effects. 2007 IEEE International Symposium on Industrial Electronics, 1242-1247. https://doi.org/10.1109/ISIE.2007.4374776

Alwash, J.H., \& Qaseer, L.J. (2010). Three-dimension finite element analysis of a helical motion induction motor. ACES Journal-Applied Computational Electromagnetics Society, 25(8), 703.

Amiri, E. (2014). Circuit modeling of double-armature rotarylinear induction motor. IECON $2014-40^{\text {th }}$ Annual Conference of the IEEE Industrial Electronics Society, 431-436. https://doi.org/10.1109/IECON.2014.7048536

Amiri, E., Gottipati, P., \& Mendrela, E. (2011). 3-D space modeling of rotary-linear induction motor with twinarmature. International Conference on Electrical Energy Systems, 203-206. https://doi.org/10.1109/ICEES.2011.5725328

Amiri, E., Jagiela, M., Dobzhanski, O., \& Mendrela, E. (2013). Modeling dynamic end effects in rotary armature of rotarylinear induction motor. International Electric Machines \& Drives Conference, 1088-1091. https://doi.org/10.1109/IEMDC.2013.6556231

Bentia, I., \& Szabo, L. (2010). Rotary-linear machines-A survey. Journal of Computer Science and Control Systems, $3(2), 11$.

Bolognesi, P., Bruno, O., Papini, F., Biagini, V., \& Taponecco, L. (2010). A low-complexity rotary-linear motor useable for actuation of active wheels. SPEEDAM 2010, 331-338. https://doi.org/10.1109/SPEEDAM.2010.5542283

Cathey, J.J. (1985). Helical motion induction motor. IEE Proceedings B-Electric Power Applications, 132(2), 112-114. https://doi.org/10.1049/ip-b.1985.0015

Dobzhanskyi, O., \& Gouws, R. (2013). Study on energy savings applying highly efficient permanent magnet motor with two degrees of mechanical freedom in concrete industry. Proceedings of the $10^{\text {th }}$ Industrial and Commercial Use of Energy Conference, 1-5.

Fleszar, J., \& Mendrela, E.A. (1983). Twin-armature rotarylinear induction motor. IEE Proceedings B (Electric Power Applications), 130(3), 186-192. https://doi.org/10.1049/ip-b.1983.0027

Gieras, J., \& Saari, J. (2012). Performance calculation for a high-speed solid-rotor induction motor. IEEE transactions on industrial electronics, 2689-2700. https://doi.org/10.1109/TIE.2011.2160516

Kim, K., \& Ivanov, S. (2009). On the problem of determining speed-torque characteristics of thermal electromechanical converters. Russian Electrical Engineering, 80(8), 459-465. https://doi.org/10.3103/S1068371209080094

Mendrela, E. (1978). Rotary-linear induction motor. IEEE Winter Power Mtng.

Mendrela, E.A., \& Gierczak, E. (1987). Double-winding rotarylinear induction motor. IEEE Transactions on Energy Conversion, (1). 47-54. https://doi.org/10.1109/TEC.1987.4765803

Papini, L., \& Gerada, C. (2014) Analytical-numerical modelling of solid rotor induction machine. Electrimacs, 121-126. 
Rabiee, M., \& Cathey, J.J. (1988). Verification of a field theory analysis applied to a helical motion induction motor. IEEE Transactions on Magnetics, 24(4), 2125-2132. https://doi.org/10.1109/20.3415

Szczygieł, M., \& Kluszczyński, K. (2016). Rotary-linear induction motor based on the standard 3-phase squirrel cage induction motor-constructional and technological features. Czasopismo Techniczne. Elektrotechnika, 395-406. https://doi.org/10.4467/2353737XCT.15.059.3859

Zablodskiy, N., Pliugin, V., \& Gritsyuk, V. (2014). Submersible electromechanical transformers for energy efficient technologies of oil extraction. Progressive Technologies of Coal, Coaled Methane, And Ores Mining, 223-227. https://doi.org/10.1201/b17547-40
Zablodskiy, N., Plyugin, V., \& Gritsyuk, V. (2016). Polyfunctional electromechanical energy transformers for technological purposes. Russian Electrical Engineering, 87(3), 140-144. https://doi.org/10.3103/S1068371216030123

Zablodskiy, N., Zhiltsov, A., Kondratenko, I., \& Gritsyuk, V. (2017). Conception of efficiency of heat electromechanical complex as hybrid system. Electrical and Computer Engineering, IEEE First Ukraine Conference, 399-404. https://doi.org/10.1109/UKRCON.2017.8100519

Zhao, J., Liu, X., Xin, Z., \& Han, Y. (2009). Research on the energy-saving technology of concrete mixer truck. $4^{\text {th }}$ IEEE Conference on Industrial Electronics and Applications, 3551-3554.

https://doi.org/10.1109/iciea.2009.5138867

\section{D МОДЕЛЬ ЕЛЕКТРОМАГНІТНОГО ПОЛЯ ШНЕКОВОГО ЕЛЕКТРОМЕХАНІЧНОГО ПЕРЕТВОРЮВАЧА IЗ ЗОВНІШНІМ МАСИВНИМ РОТОРОМ}

\section{М. Заблодський, В. Грицюк, Є. Руднєв, Р. Брожко}

Мета. Створення тривимірної математичної моделі електромагнітного поля шнекового електромеханічного перетворювача із зовнішнім масивним ротором, що враховує особливості геометрії і фактор кінцевої довжини.

Методика. Розрахунок розподілу електромагнітного поля виконаний із використанням чисельного рішення диференціальних рівнянь методом кінцевих елементів в тривимірній постановці.

Результати. Встановлено, що у повітряному зазорі значення магнітної індукції змінюються в діапазоні $0.7-0.8$ Тл, в ніжках зубців статора досягають величини 2 Тл. Індукція в порожнистому феромагнітному роторі переважно змінюється в діапазоні $1.3-2.0$ Тл, а в тонкому шарі товщиною $1.0-1.5$ мм, зверненому до поверхні статора, досягає величини 2.3 Тл. В межах одного полюсного поділу максимум $z$-компоненти густини вихрових струмів становить $18 \cdot 10^{6} \mathrm{~A} / \mathrm{M}^{2}$ на внутрішній поверхні порожнистого ротора. Визначено, що за винятком "крайових" ділянок ротора, де переважає поперечна складова вихрових струмів, а також ділянок "входу" магнітного потоку в ротор, вихрові струми в основному є аксіальними. Порівняння результатів вимірювання напруженості електричного поля на поверхні ротора показало відмінність даних не більше 4\%. Запропонована модель дозволяс оптимізувати конструкцію перетворювача, зокрема, зменшити магнітну індукцію в зубцях статора.

Наукова новизна. Отримано чисельні результати у вигляді просторових картин розподілу та графічних залежностей, які повністю враховують аксіальну та тангенціальну компоненти електромагнітного поля.

Практична значимість. Розглянута кінцево-елементна модель може бути використана при аналізі електромагнітних полів в електромеханічних перетворювачах зі складною вторинної частиною. Це дозволить врахувати реальний тривимірний характер поля, викликаний особливостями конструкції і кінцевими осьовими розмірами.

Ключові слова: вугільний концентрат, шнековий електромеханічний перетворювач, чисельні дослідження, магнітна індукиія, розподіл вихрових струмів

\section{D МОДЕЛЬ ЭЛЕКТРОМАГНИТНОГО ПОЛЯ ШНЕКОВОГО ЭЛЕКТРОМЕХАНИЧЕСКОГО ПРЕОБРАЗОВАТЕЛЯ С ВНЕШНИМ МАССИВНЫМ РОТОРОМ}

\section{Н. Заблодский, В. Грицюк, Е. Руднев, Р. Брожко}

Цель. Создание трехмерной математической модели электромагнитного поля шнекового электромеханического преобразователя с внешним массивным ротором, учитывающей особенности геометрии и фактор конечной длины.

Методика. Расчет распределения электромагнитного поля выполнен с использованием численного решения дифференциальных уравнений методом конечных элементов в трехмерной постановке.

Результаты. Установлено, что в воздушном зазоре значения магнитной индукции изменяются в диапазоне $0.7-0.8$ Тл, в ножках зубцов статора достигают величины 2 Тл. Индукция в полом феромагнитном роторе преимущественно изменяется в диапазоне $1.3-2.0$ Тл, а в тонком слое толщиной $1.0-1.5$ мм, обращенном к поверхности статора, достигает величины 2.3 Тл. В пределах одного полюсного деления максимум $z$-компоненты плотности вихревых токов составляет $18 \cdot 10^{6} \mathrm{~A} / \mathrm{M}^{2}$ на внутренней поверхности полого ротора. Определено, что за исключением "краевых" участков ротора, где преобладает поперечная составляющая вихревых токов, а также участков "входа" магнитного потока в ротор, вихревые токи в основном являются аксиальными. Сопоставление результатов измерения напряженности электрического поля на поверхности ротора показало различие данных не более $4 \%$. Предложенная модель позволяет оптимизировать конструкцию преобразователя, в частности, снизить магнитную индукцию в зубцах статора.

Научная новизна. Получены численные результаты в виде пространственных картин распределения и графических зависимостей, которые полностью учитывают аксиальную и тангенциальную компоненты электромагнитного поля. 
Практическая значимость. Рассмотренная конечно-элементная модель может быть использована при анализе электромагнитных полей в электромеханических преобразователях со сложной вторичной частью. Это позволит учесть реальный трехмерный характер поля, вызванный особенностями конструкции и конечными осевыми размерами.

Ключевые слова: угольный концентрат, инековый электромеханический преобразователь, численные исследования, магнитная индукиия, распределение вихревых токов

\section{ARTICLE INFO}

Received: 17 May 2019

Accepted: 6 November 2019

Available online: 4 December 2019

\section{ABOUT AUTHORS}

Mykola Zablodskiy, Doctor of Technical Sciences, Professor of the Department of Electrical Engineering, Electromechanics and Electrotechnology, National University of Life and Environmental Sciences of Ukraine, 15 Heroiv Oborony St, 03041, Kyiv, Ukraine. E-mail: zablodskiynn@gmail.com

Volodymyr Gritsyuk, Candidate of Technical Sciences, Associate Professor of the Electrical Engineering Department, Volodymyr Dahl East Ukrainian National University, 59a Central Ave., 93400, Sieverodonetsk, Ukraine. E-mail: gritsyukvy@gmail.com

Yevgen Rudnev, Candidate of Technical Sciences, Associate Professor of the Electrical Engineering Department, Volodymyr Dahl East Ukrainian National University, 59a Central Ave., 93400, Sieverodonetsk, Ukraine. E-mail: rudnev_evgen@mail.ru

Rostislav Brozhko, Candidate of Technical Sciences, Associate Professor of the Electrical Engineering Department, Volodymyr Dahl East Ukrainian National University, 59a Central Ave., 93400, Sieverodonetsk, Ukraine. E-mail: slavonx5x5x5@gmail.com 